\title{
INVESTORS' REACTIONS TO ENVIRONMENTAL DISCLOSURES: EVIDENCE FROM BORSA ISTANBUL
}

\author{
ÇEVRE İLE İLGILII AÇIKLAMALARA YATIRIMCILARIN TEPKILERİ: \\ BORSA ISTANBUL ÜZERINE BİR ARAŞTIRMA
}

\author{
V. Evrim ALTUK ÖZTÜRK* \\ Ayşegüil İSCANOĞLU ÇEKİÇ ${ }^{* *}$ iD
}

\begin{abstract}
The goal of this study is to analyze the impacts of the environmental corporate social responsibility on stock performances. In other words, this study aims to measure investors' reactions to environmental awareness. In this regard, we consider listing in the BIST Sustainability Index as an environmental awareness and we implement an event study around the announcement of the companies included in the BIST Sustainability Index. This study covers the daily stock prices of 59 companies indexed in the BIST Sustainability Index between 2014-2019. The eight different event windows are considered. According to the findings of the study, no significant performance change is observed in the companies included or delisting from the sustainability index in short time.
\end{abstract}

Keywords: Event Study, BIST Sustainability Index, Environmental Awareness, Stock Performance

JEL Classification: G14, M41, Q56

Öz

Bu çalışmanın amacı, şirketlerin çevreye ilişkin sosyal sorumluluklarının hisse senedi performansına etkisini analiz etmektir. Bir başka ifadeyle çevre duyarlılığına yatırımcı tepkilerinin ölçmeyi hedeflemektedir. Bu bağlamda, BIST Sürdürülebilirlik Endeksi’nde yer alan şirketler, çevresel duyarlılığı olan şirketler olarak ele alındı ve BIST Sürdürülebilirlik Endeksi’ndeki şirketlerin duyuruları çerçevesinde bir olay çalışması uygulandı. Bu çalışma, 2014-2019 yılları arasında BIST Sürdürülebilirlik Endeksi’nde yer alan 59 şirketin günlük hisse senedi fiyatlarını kapsamaktadır. Çalışmada, sekiz farklı olay penceresi dikkate alınmıştır. Araştırmanın bulgularına göre, sürdürülebilirlik endeksine dâhil edilen veya çıkarılan şirketlerde, kısa dönemde, önemli bir performans değişikliği gözlemlenmemiştir.

Anahtar Kelimeler: Olay Çalışması, BIST Sürdürülebilirlik Endeksi, Çevresel Duyarlılık, Hisse Senedi Performans 1

JEL Sınıflandırması: G14, M41 Q56

Asst. Prof. Dr., Trakya University, Department of Accounting and Finance Management, E-Mail: evrima@trakya.edu.tr, ORCID ID: 0000-0003-2139-8081

** Assoc. Prof. Dr., Trakya University, Department of Econometrics, Edirne, E-Mail: aysegulcekic@trakya.edu.tr, ORCID ID: 0000-0003-0692-7870 


\section{Introduction}

The resources of our world are running out due to human activities. Therefore, the renewal of resources is extremely important for humans. At this point, sustainability becomes a necessity to make the world a better place to live.

Today, the importance of sustainability has been understood in many areas and an increasing environmental awareness has been created. While most consumers prefer environmentally friendly products, some investors consider sustainability as well as profitability. Changes in consumer and investor perspectives encourage companies to produce recyclable products and become more environmentally friendly. This is actually so called stakeholder theory which states that companies should care about all parties related to the company, such as the state, the public, investors, opponents, customers, employees ${ }^{1}$.

This study is about the reactions of the investors to the environmental disclosures of the companies. In other words, our hypothesis is that investors react to companies' environmental awareness and precautions and as a result, if the company takes necessary environmental precautions then it's earnings will increase.

In this context, our hypothesis adopts the following views. Companies that prefer to be socially responsible undertake Corporate Social Responsibility (CSR) activities ${ }^{2}$ and this behavior is a great opportunity to create permanent value for many stakeholders ${ }^{3}$. Sustainability will increase reputation, increase in reputation will increase sales and thus companies will create financial value with increased earnings and reduced costs.

For this reason, we have three research questions; how to measure environmental awareness of the companies, how to measure financial performance of the companies and how to measure the reaction of the investors.

Here the answer to our first question is sustainability reporting. The concept of sustainability reporting has emerged in the late $1980 \mathrm{~s}^{4}$. This report allows investors to learn more about the risks and opportunities associated with social, economic and environmental factors, as well as to have accounting data that will affect stock prices ${ }^{5}$.

1 Ziegler, A. et al. (2011). Disclosed Corporate Responses to Climate Change and Stock Performances: An International Empirical Analysis, Energy Economics, 33(6): 1283-1294.

2 Shakil, M.H. et al. (2019). Do Environmental, Social and Governance Performance Affect the Financial Performance of Banks? A Cross-Country Study of Emerging Market Banks, Management of Environmental Quality, 30(6): 1331-1344.

3 Epstein, M. J. (2018). Making Sustainability Work: Best Practices in Managing and Measuring Corporate Social, Environmental and Economic Impacts, Routledge

Eccles, R. G., Serafeim, G. (2013). A Tale of Two Stories: Sustainability and the Quarterly Earnings Call, Journal of Applied Corporate Finance, 25(3): 8-19.

4 Sustainability Reporting, https://en.wikipedia.org/wiki/Sustainability_reporting, (Accessed on: February 6, 2021)

5 Carnevale, C., Mazzuca, M. (2014). Sustainability Report and Bank Valuation: Evidence from European Stock Markets, Business Ethics: A European Review, 23(1): 69-90. 
Nowadays, since reliable and comparable Environmental, Social and Governance (ESG) reports help investors in order to make their decisions, investors have an increasing demand on ESG Reports. Therefore, more companies have started to publish ESG Reports to meet this need ${ }^{6}$. While sustainability reports mediate the sharing of environmental activities with shareholders, improvement in processes and reductions in fines imposed by regulatory agencies help reduce costs ${ }^{7}$. Extending the explanations in the reports will reduce the information asymmetry and investors will be able to decide whether a company is good at managing carbon emissions and equipped to deal with such risks ${ }^{8}$.

Our second research has not only one answer. Actually, there are two ways to assess financial performance which are accounting-based and market-based performance. Accounting-based performance indicators mainly include return on equity, return on asset, rate on sales which are based on the information obtained from corporate financial statements while market-based performance includes share price and mutual funds ${ }^{9}$. On the other hand, market-based performance is measured by stock returns and volatility.

Combining financial performance with investor's reactions event study is our methodology, the event study overlaps with our problem in that it is a method used to demonstrate the reactions of investors and the market to corporate announcements published directly by companies. On this perspective we consider ESG report publishing date as an announcement date (or event) and we try to measure changes in market-based performance with event study. For this purpose, we consider 59 companies which issue sustainability reports in 2014-2019.

This study contributes the literature in several ways. In the study, we analyze investors reactions by considering 59 companies with eight different event windows. Accordingly, this study measures the effects of inclusion or delisting from sustainability index on stock performances. Moreover, this study provides evidence of the link between stock prices and environmental disclosures.

The paper is structured as follows. In the next section a brief literature review is presented. Section 2 reviews the methodology. Section 3 summarizes the findings. The final section concludes the paper and discusses the results.

\section{Literature Review}

There are numerous studies investigating investors' reactions to the statements of companies related to environmental issues. Some of them analyze investors' reactions to environment-friendly companies and environmentally hazardous companies while the others focus on investors' reactions to companies which release sustainability reports.

6 Wong, KTK. (2017). A Literature Review on Environmental, Social and Governance Reporting and Its Impact on Financial Performance, Austin Journal of Business Administration and Management, 1(4): 1016.

$7 \quad$ Epstein, 2018.

8 Liu, Y. et al. (2017). Corporate Carbon Emissions and Financial Performance: Does Carbon Disclosure Mediate the Relationship in the UK?, Available at SSRN 2941123.

9 Liu et al., 2017; Peloza, J. (2009). The Challenge of Measuring Financial Impacts from Investments in Corporate Social Performance. Journal of Management, 35(6), 1518-1541. 
Chan and Milne ${ }^{10}$ used an experimental design to examine whether investors react badly or well to performing companies. Their findings revealed that investors tended to react strongly and negatively to the companies performing poorly while they did not have significantly better reactions to environmental performers.

Ziegler et al. ${ }^{11}$ investigated European and US stock markets to determine whether there is a relationship between disclosed corporate responses to climate change and stock performances from 2001 to 2006. Their results showed that investors buy stocks of companies with higher levels of responses to climate change in Europe. They also found a positive relationship between disclosed responses to climate change and stock performances for energy firms in the USA.

Murgia and Lence ${ }^{12}$ used event study to analyze whether the release of Newsweek's "Global 100 Green Rankings" is relevant to the market. They investigated investors' reactions to the "Global 100 Ranking" by considering the changes in the relative price of the stocks.

Liu et al. ${ }^{13}$ found out that market responses react to excessive carbon emission.

Murray et al. ${ }^{14}$ investigated the link between market returns and the tendency to undertake social and environmental disclosure in UK companies. They did not find a direct relationship between share returns and disclosure. However, they found a positive relationship between returns and the predilection for disclosure.

Berthelot et al. ${ }^{15}$ investigated whether investors value the publication of sustainability reports of the Canadian companies listed on Toronto Stock Exchange. The findings suggest that investors react positively to these reports.

Carnevale and Mazzuca ${ }^{16}$ studied the direct effects of sustainability reports of European Banks on stock prices. Their results indicated that the reports had a positive effect on stock prices and that the statements in the reports are noted by the investors. The statements in the sustainability reports seem to prevent information asymmetry, thus helping investors with their decisionmaking.

10 Chan, C. C., Milne, M. J. (1999). Investor Reactions to Corporate Environmental Saints and Sinners: An Experimental Analysis, Accounting and Business Research, 29(4): 265-279.

11 Ziegler, A., Busch, T., Hoffmann, V. H. (2011). Disclosed Corporate Responses to Climate Change and Stock Performances: An International Empirical Analysis, Energy Economics, 33(6): 1283-1294.

12 Murguia, J. M., Lence, S. H. (2015). Investors' Reaction to Environmental Performance: A Global Perspective of the Newsweek's “Green Rankings”, Environmental and Resource Economics, 60(4): 583-605.

13 Liu et al., 2017.

14 Murray, A., Sinclair, D., Power, D., Gray, R. (2006). Do Financial Markets Care About Social and Environmental Disclosure?, Accounting, Auditing \& Accountability Journal, 19(2): 228-255.

15 Berthelot, S., Coulmont, M., Serret, V. (2012). Do Investors Value Sustainability Reports? A Canadian study, Corporate Social Responsibility and Environmental Management, 19(6): 355-363.

16 Carnevale, Mazzuca, 2014. 
Çitak and Ersoy ${ }^{17}$ reviewed the difference between the companies in the BIST-30 Index and the companies that are not included in the BIST Sustainability Index with respect to their financial performance in January-March 2014. They employed event study as the research method to investigate the investor reactions to their announcement that they would be included in the sustainability index. Although investors' short-term decisions did not seem to be affected, positive reactions were given for the whole three days following the date of announcement.

Du et al. ${ }^{18}$ investigated investors' reactions to sustainability reports using event study method. Their results revealed that investors tend to give significant reactions to sustainability reports in the short run.

Çitak et al. ${ }^{19}$ compared the investor reactions to BIST Sustainability Index and non-BIST Sustainability Index companies. They did not find a significant difference between in the mean and median. However, cumulative abnormal returns were positive for the data windows for 4, 5, 7, 8, 9 and 10 days, which suggests that investors have increasingly begun to react.

Aureli et al. ${ }^{20}$ reviewed the companies in Dow Jones Sustainability World Index between 2009 and 2016 and underlined that the release of ESG (Environmental, Social and Governance) Reports had a significant contribution to their market cap.

Wasara and Ganda ${ }^{21}$ investigated the mining companies listed on Johannesburg Stock Exchange from 2010 to 2014 to test whether there is a relationship between return on investment and environmental and social disclosures in the sustainability reports. They found a positive link between corporate social disclosure and return on investment while there was a negative link between environmental disclosure and return on investment.

Çimen ${ }^{22}$ used event study analysis to find out whether there is a relationship between companies listed in Sustainability Index and their stock returns in Borsa Istanbul. The results show that the announcement of Borsa Istanbul and the inclusion of the index have positive impact on the companies' financial performance and the companies also experience abnormal returns.

17 Çıtak, L., Ersoy, E. (2016). Firmaların BIST Sürdürülebilirlik Endeksine Alınmasına Yatırımcı Tepkisi: Olay Çalışması ve Ortalama Testleri ile Bir Analiz (Investors' Reactions to the Inclusion of Firms in the BIST Sustainability Index: An Analysis by Event Study and Mean-Median Tests), International Journal of Alanya Faculty of Business, 8(1): 43-57.

18 Du, S., Yu, K., Bhattacharya, C. B., Sen, S. (2017). The Business Case for Sustainability Reporting: Evidence from Stock Market Reactions, Journal of Public Policy \& Marketing, 36(2): 313-330.

19 Çitak, L., Akel, V., Ersoy, E. (2020). Investors' Reactions to the Announcement of New Constituents of BIST Sustainability Index: An Analysis by Event Study and Mean-Median Tests." Value Sharing for Sustainable and Inclusive Development, IGI Global, 2018: 270-289.

20 Aureli, S., Gigli, S., Medei, R., Supino, E. (2019). The Value Relevance of Environmental, Social, and Governance Disclosure: Evidence from Dow Jones Sustainability World Index Listed Companies, Corporate Social Responsibility and Environmental Management, 27(1): 43-52.

21 Wasara, T. M., Ganda, F. (2019). The Relationship Between Corporate Sustainability Disclosure and Firm Financial Performance in Johannesburg Stock Exchange (JSE) Listed Mining Companies, Sustainability, 11(16): 4496.

22 Çimen, A. (2019). The Impact of Sustainability Index on Firm Performance: An Event Study. International Journal of Contemporary Economics and Administrative Sciences, 9(1): 170-183. 


\section{Methodology}

This study is methodologically related to the event study. Event studies are based on the efficient market hypothesis ${ }^{23}$ and defined as a series of methods which are used to investigate the changes in stock prices of companies following some bad/good news about the companies. The event may take place at different moments over time, or may be clustered over a period of time ${ }^{24}$.

An event study procedure can be illustrated as in Figure 1.

\section{Figure 1: Event Study}
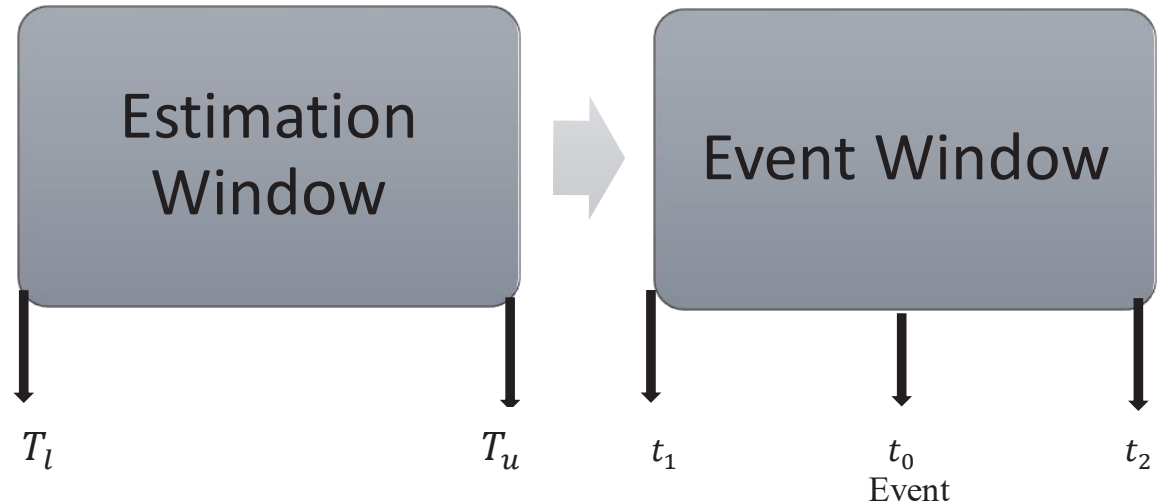

In Figure 1, $T_{l}$ and $T_{u}$ shows the lower and upper bounds of the estimation window, respectively. Then the time of event is assumed to be $t_{0}$ and an event analysis is implemented on $t_{1} \leq t_{0} \leq t_{2}$ which is so called event window.

In this study, any announcement of companies listed in the sustainability index is defined as an event. We investigate whether the market-based performances of the companies listed in, included in or delisting from the BIST Sustainability Index are changed with the event.

In other words, we test the hypotheses given in (1) - (3).

$H_{0}$ : Listed in the sustainability index has no effect on market-based performances of companies.

$H_{1}$ : Listed in the sustainability index increases the market-based performances of companies.

$H_{0}$ : Inclusion to the sustainability index has no effect on market-based performances of companies.

$H_{1}$ : Inclusion to the sustainability index increases the market-based performances of companies.

$H_{0}$ : Delisting from the sustainability index has no effect on market-based performances of companies.

$H_{1}$ : Delisting from the sustainability index decreases the market-based performances of companies.

23 Fama, E. (1991). Efficient Capital Markets: II, Journal of Finance, 46: 1575-1617.

24 Kothari, S. P., Warner, J. B. (2006). Econometrics of Event Studies, Chapter 1 in Handbook of Corporate Finance: Empirical Corporate Finance. 
In an event study whether the distribution of returns during an event window is abnormal than expected is investigated. For this reason, firstly the returns are calculated. Then, by using estimation window data, abnormal returns are obtained with the help of expected return model (e.g., market model, capital asset pricing model, factor models etc. $)^{25}$.

Kothari and Warner (2006) state that in the event studies the use of daily (and sometimes intraday) returns is more common than that of monthly returns. Because using daily returns allows for more precise measurement of abnormal returns and for better detection of announcement effects. Moreover, they also state that event studies can be implemented by using two different time horizons; short-horizon and long-horizon. Event studies that focus on the announcement effects of the shorthorizon related to an event provide relevant evidence to understand corporate policy decisions. On the other hand, event studies that focus on the announcement effects of the long-horizon related to an event provide relevant evidence of market efficiency.

Following Kothari and Warner (2006) we construct our methodology, which includes as follows:

\section{Step 1}

The daily logarithmic returns given in (4) of each company are calculated.

$$
R_{i t}=\ln \left(P_{i, t}\right)-\ln \left(P_{i, t-1}\right) \text {. }
$$

where $P_{i, t}$ is the stock price of the company $i$ at time $t$.

\section{Step 2}

The market model which is defined in (5) is applied.

$$
R_{i t}=\beta_{0 i}+\beta_{1 i} R_{m t}+\varepsilon_{i t}
$$

where $R_{i t}$ is the return of the company $i$ at time $t, R_{m t}$ is the market return, $\beta_{1 i}$ is the sensitivity of the company $i$ to the market and $\varepsilon_{i t}$ is the unexpected return at the time $t$. which is called "Abnormal Return".

In other words, if we denote abnormal return of the company $i$ at time $t$ as $A R_{i t}$. Then, $A R_{i t}$ is written

$$
A R_{i t}=R_{i t}-\beta_{0 i}-\beta_{1 i} R_{m t}
$$

follows:

At this step we use 1-year estimation window which is started 1-day after the announcement and ended 1-month before the event date. Moreover, we use BIST100 as the market index.

\section{Step 3}

Since abnormal return is only 1-day unexpected return, one day is not enough to understand the impact of an event ${ }^{26}$. Therefore, we consider the Cumulative Abnormal Returns (CAR) which is defined in (7) for the event window.

25 Kothari, Warner, 2006.

26 Tellis, G. J., Johnson, J. (2007), The Value of Quality, Marketing Science, 26(6): 758-773. 


$$
C A R_{1}=\sum_{t=t_{1}}^{t_{2}} A R_{i t}
$$

In the analysis, we consider eight different event windows which are listed as follows:

Event Window 1: $t_{1}=0$ to $t_{2}=3$ (4-days)

Event Window 2: $t_{1}=0$ to $t_{2}=5$ (6-days)

Event Window 3: $t_{1}=0$ to $t_{2}=10$ (11-days)

Event Window 4: $t_{1}=0$ to $t_{2}=20$ (21-days)

Event Window 5: $t_{1}=-3$ to $t_{2}=3$ (7-days)

Event Window 6: $t_{1}=-5$ to $t_{2}=5$ (11-days)

Event Window 7: $t_{1}=-10$ to $t_{2}=10$ (21-days)

Event Window 8: $t_{1}=-20$ to $t_{2}=20$ (41-days)

\section{Step 4}

Finally, nonparametric CAR test is implemented ${ }^{27}$. In these tests, under the null hypothesis event does not have effect, in other words, there is no abnormal returns.

\section{Empirical Results}

In this study, our data cover 59 companies which publish sustainability reports and are listed in the BIST sustainability index in the period from 2014 to 2019. In the analysis, we use daily logarithmic returns. All the applications are implemented on $R^{28}$ and CAR values are calculated by using $R$ package called "estudy2"29.

Accordingly, we consider daily stock prices of 60 companies listed in the Borsa Istanbul Sustainability Index for the period from 2014 to 2019. However, in 2017 SAF REIT merges with Akis REIT and therefore, SAF REIT's shares have not been traded anymore. Therefore, we exclude SAFGY from our sample. We continue with 59 companies.

We collect daily closing prices data from "finance.yahoo.com" database for the period from November 4, 2013 to January 3, 2020.

27 Corrado C. J. (1989). A Nonparametric Test for Abnormal Security-Price Performance in Event Studies, Journal of Financial Economics, 23: 385-395; Cowan A. R. (1992). Nonparametric Event Study Tests. Review of Quantitative Finance and Accounting, 2: 343-358.

28 R Core Team (2020). R: A language and Environment for Statistical Computing, R Foundation for Statistical Computing, Vienna, Austria. URL https://www.R-project.org/

29 Rudnytskyi, I. (2019). Estudy2: An Implementation of Parametric and Nonparametric Event Study, R package version 0.9.1. 
We firstly apply Augmented Dickey Fuller test ${ }^{30}$ for stationarity and Jarque Bera test ${ }^{31}$ for normality of return series. According to results all return series are stationary and do not follow normal distribution.

Our event dates are listed in Table 1 which are actually announcement dates of the companies included in the BIST Sustainability index. Table 1 also includes the number of companies in index.

Table 1: Announcement Dates, Index Calculation Period and Number of Companies in Sustainability Index

\begin{tabular}{|l|l|l|l|}
\hline Year & Period of Index & Announcement Date & $\begin{array}{l}\text { Number of } \\
\text { Companies }\end{array}$ \\
\hline $\mathbf{2 0 1 4 - 2 0 1 5}$ & November 2014-October 2015 & November 4, 2014 & 15 \\
\hline $\mathbf{2 0 1 5 - 2 0 1 6}$ & November 2015-October 2016 & November 3, 2015 & 29 \\
\hline $\mathbf{2 0 1 6 - 2 0 1 7}$ & November 2016-October 2017 & October 25, 2016 & 43 \\
\hline $\mathbf{2 0 1 7 - 2 0 1 8}$ & November 2017-October 2018 & October 27, 2017 & 44 \\
\hline $\mathbf{2 0 1 8 - 2 0 1 9}$ & November 2018-October 2019 & October 27, 2018 & 50 \\
\hline $\mathbf{2 0 1 9 - 2 0 2 0}$ & November 2019-October 2020 & October 25, 2019 & 56 \\
\hline
\end{tabular}

Estimation window and stock names included and delisting from the index are listed in Table 2.

Table 2: Estimation Window, Shares Included and Delisting

\begin{tabular}{|l|l|l|l|}
\hline Year & $\begin{array}{l}\text { Estimation Window } \\
\text { (Start Date; End Date })\end{array}$ & $\begin{array}{l}\text { Shares included to the } \\
\text { Sustainability Index }\end{array}$ & $\begin{array}{l}\text { Shares Delisting from } \\
\text { the Sustainability Index }\end{array}$ \\
\hline $\mathbf{2 0 1 4 - 2 0 1 5}$ & $2013-11-04 ; 2014-10-03$ & $\begin{array}{l}\text { AKBNK, ARCLK, ASELS, GARAN, } \\
\text { KCHOL, MGROS, PETKM, } \\
\text { SAHOL, TAVHL, TCELL, TOASO, } \\
\text { TUPRS, TTKOM, VAKBN, YKBNK }\end{array}$ & - \\
\hline $\mathbf{2 0 1 5 - 2 0 1 6}$ & $2014-11-05 ; 2015-10-02$ & $\begin{array}{l}\text { AEFES, AKSEN, BRISA, CCOLA, } \\
\text { DOAS, EREGL, FROTO, ISCTR, } \\
\text { OTKAR, SAFG THYAO, TSKB, } \\
\text { ULKER, VESTL }\end{array}$ & - \\
\hline $\mathbf{2 0 1 6 - 2 0 1 7}$ & $2015-11-04 ; 2016-09-24$ & $\begin{array}{l}\text { ADEL, DOHOL, GLYHO, HALKB, } \\
\text { ISGYO, KORDS, NETAS, PGSUS, } \\
\text { SISE, TATGD, TKFEN, TTRAK, } \\
\text { VESBE, ZOREN }\end{array}$ & - \\
\hline $\mathbf{2 0 1 7 - 2 0 1 8}$ & $2016-10-26 ; 2017-09-26$ & $\begin{array}{l}\text { AKENR, CIMSA, LOGO, POLHO, } \\
\text { SODA }\end{array}$ & ADEL, GLYHO, ISGYO \\
\hline $\mathbf{2 0 1 8 - 2 0 1 9}$ & $2017-10-28 ; 2018-09-26$ & $\begin{array}{l}\text { AKSA, ANACM, ANELE, AYGAZ, } \\
\text { GLYHO, SKBNK }\end{array}$ & - \\
\hline $\mathbf{2 0 1 9 - 2 0 2 0}$ & $2018-10-28 ; 2019-09-24$ & $\begin{array}{l}\text { ALBRK, ENJSA, ENKAI, ISDMR, } \\
\text { KERVT, SOKM, TRKCM }\end{array}$ & PGSUS \\
\hline
\end{tabular}

30 Dickey, D. A., Fuller, W. A. (1979). Distribution of the Estimators for Autoregressive Time Series with A Unit Root, Journal of the American Statistical Association, 74(366): 427-431.

31 Jarque, C., Bera, A. (1987). A Test for Normality of Observations and Regression Residuals, International Statistical Review, 55: 163-172. 
Then, CAR Nonparametric rank test is implemented to test the significant changes in the stock performances. The test statistics and their significances are given in Table 3-5 for each hypothesis given in (1) to (3), respectively.

Table 3. Nonparametric Rank Test Statistics of Hypothesis given in (1)

\begin{tabular}{|l|c|c|c|c|c|c|}
\hline & $\mathbf{2 0 1 4 - 2 0 1 5}$ & $\mathbf{2 0 1 5 - 2 0 1 6}$ & $\mathbf{2 0 1 6 - 2 0 1 7}$ & $\mathbf{2 0 1 7 - 2 0 1 8}$ & $\mathbf{2 0 1 8 - 2 0 1 9}$ & $\mathbf{2 0 1 9 - 2 0 2 0}$ \\
\hline Event Window 1 & 1.6267 & -0.0177 & -0.1124 & -1.3658 & -0.8129 & 0.5022 \\
\hline Event Window 2 & 1.0025 & 0.5301 & -0.6093 & -1.2705 & -0.2853 & 0.5725 \\
\hline Event Window 3 & 0.6806 & 1.1983 & -0.4587 & -0.2532 & 0.3115 & 0.8202 \\
\hline Event Window 4 & 1.0634 & 0.3507 & -0.2244 & -0.0575 & 0.0844 & 1.1782 \\
\hline Event Window 5 & 1.3239 & 0.3991 & -0.3341 & -0.5226 & -0.3654 & 0.5521 \\
\hline Event Window 6 & 0.8307 & 0.4960 & -0.9702 & -0.3053 & -0.4775 & 1.2382 \\
\hline Event Window 7 & -0.2798 & 0.8643 & -0.7253 & 0.4846 & 0.6790 & 1.2540 \\
\hline Event Window 8 & 0.7692 & 0.2799 & -0.6087 & -0.0883 & -0.4973 & 1.0745 \\
\hline
\end{tabular}

Table 4. Nonparametric Rank Test Statistics of Hypothesis given in (2)

\begin{tabular}{|l|c|c|c|c|c|}
\hline & $\mathbf{2 0 1 5 - 2 0 1 6}$ & $\mathbf{2 0 1 6 - 2 0 1 7}$ & $\mathbf{2 0 1 7 - 2 0 1 8}$ & $\mathbf{2 0 1 8 - 2 0 1 9}$ & $\mathbf{2 0 1 9 - 2 0 2 0}$ \\
\hline Event Window 1 & 0.0388 & -0.5595 & -0.8736 & -0.2844 & -0.6268 \\
\hline Event Window 2 & 0.9870 & -0.9549 & -1.3355 & 0.1242 & -0.2181 \\
\hline Event Window 3 & 1.5562 & -0.7205 & -0.7051 & 0.0797 & -0.6390 \\
\hline Event Window 4 & 1.0513 & -0.2087 & 0.0682 & -0.2139 & 0.5880 \\
\hline Event Window 5 & 0.1989 & -0.6724 & 0.3346 & -1.0622 & -0.6834 \\
\hline Event Window 6 & 0.5759 & -0.9873 & 0.0921 & -0.9904 & 0.0152 \\
\hline Event Window 7 & 0.8306 & -0.5029 & 0.2612 & 0.2940 & -0.2882 \\
\hline Event Window 8 & 0.7119 & -0.2364 & 0.1422 & -0.7264 & 0.8010 \\
\hline
\end{tabular}

Table 5. Nonparametric Rank Test Statistics of Hypothesis given in (3)

\begin{tabular}{|l|c|c|}
\hline & $\mathbf{2 0 1 7 - 2 0 1 8}$ & $\mathbf{2 0 1 9 - 2 0 2 0}$ \\
\hline Event Window 1 & -0.4424 & 0.9082 \\
\hline Event Window 2 & -0.3457 & 0.4514 \\
\hline Event Window 3 & 0.3976 & -0.4752 \\
\hline Event Window 4 & -0.3329 & 1.1773 \\
\hline Event Window 5 & -0.5706 & 0.7506 \\
\hline Event Window 6 & -1.0306 & 1.2933 \\
\hline Event Window 7 & -0.1124 & -0.2062 \\
\hline Event Window 8 & -0.8216 & 0.5062 \\
\hline
\end{tabular}

According to Table 4-5 all the statistics are insignificant, and this implies that listed in, including in or delisting from the BIST Sustainability Index do not have effect on stock performances. 


\section{Conclusion}

This study empirically analyzes the impact of Turkish companies' environmental corporate social responsibility on stock performances. By doing that this study also investigates the investors' reactions on sustainability. In this respect, listed in, including in or delisting from the BIST Sustainability Index assumed to be an indicator of environmental responsibility.

The analysis is based on an event study. The disclosure of the BIST Sustainability Index is defined as an event. Empirically, three different hypotheses are considered. These hypotheses focus on measuring the effect of being listed in the BIST sustainability index on stock performances, the effect of inclusion in the BIST Sustainability Index on stock performances and the effect of delisting from the BIST Sustainability Index on stock performances. In order to obtain consistent results, we implement a short-term event study with market model, where BIST100 is considered as market index. For this purpose, we calculate the cumulative abnormal returns (CAR) for 8 different event windows. Finally, a nonparametric CAR test is applied.

The findings show that being on, being included or being delisting from the sustainability index have no significant effect on stock performances. Therefore, assuming that listed in the sustainability index is an indicator of the company's environmental awareness, our results suggest that higher environmental or social performance is not financially rewarded. This result supports the view that investors in Turkish financial markets do not react sustainability and therefore environmental disclosure.

\section{References}

AURELI, S., Gigli, S., Medei, R., Supino, E. (2019). The Value Relevance of Environmental, Social, and Governance Disclosure: Evidence from Dow Jones Sustainability World Index Listed Companies, Corporate Social Responsibility and Environmental Management, 27(1): 43-52.

BERTHELOT, S., Coulmont, M., Serret, V. (2012). Do Investors Value Sustainability Reports? A Canadian Study, Corporate Social Responsibility and Environmental Management, 19(6): 355-363.

CARNEVAlE, C., Mazzuca, M. (2014). Sustainability Report and Bank Valuation: Evidence from European Stock Markets, Business Ethics: A European Review, 23(1): 69-90.

CHAN, C. C., Milne, M. J. (1999). Investor Reactions to Corporate Environmental Saints and Sinners: An Experimental Analysis. Accounting and Business Research, 29(4): 265-279.

ÇİMEN, A. (2019). The Impact of Sustainability Index on Firm Performance: An Event Study, International Journal of Contemporary Economics and Administrative Sciences, 9(1): 170-183.

ÇITAK, L., Ersoy, E. (2016). Firmaların BIST Sürdürülebilirlik Endeksine Alınmasına Yatırımcı Tepkisi: Olay Çalışması ve Ortalama Testleri ile Bir Analiz (Investors' Reactions to the Inclusion of Firms in the BIST Sustainability Index: An Analysis by Event Study and Mean-Median Tests), International Journal of Alanya Faculty of Business, 8(1): 43-57.

ÇITAK, L., Akel, V., Ersoy, E. (2020). Investors' Reactions to the Announcement of New Constituents of BIST Sustainability Index: An Analysis by Event Study and Mean-Median Tests. Value Sharing for Sustainable and Inclusive Development. IGI Global, 2018: 270-289. 
CORRADO C. J. (1989). A Nonparametric Test for Abnormal Security-Price Performance in Event Studies, Journal of Financial Economics, 23: 385-395.

COWAN A. R. (1992). Nonparametric Event Study Tests, Review of Quantitative Finance and Accounting, 2: 343-358.

DICKEY, D. A., Fuller, W. A. (1979). Distribution of The Estimators for Autoregressive Time Series with A Unit Root, Journal of the American Statistical Association, 74(366): 427-431.

DU, S., Yu, K., Bhattacharya, C. B., Sen, S. (2017). The Business Case for Sustainability Reporting: Evidence from Stock Market Reactions, Journal of Public Policy \& Marketing, 36(2): 313-330.

ECCLES, R. G., Serafeim, G. (2013). A Tale of Two Stories: Sustainability and the Quarterly Earnings Call, Journal of Applied Corporate Finance, 25(3): 8-19.

EPSTEIN, M. J. (2018). Making Sustainability Work: Best Practices in Managing and Measuring Corporate Social, Environmental and Economic Impacts. Routledge.

FAMA, E. (1998). Market Efficiency, Long-Term Returns, and Behavioral Finance, Journal of Financial Economics, 49(3): 283-306.

JARQUE, C., Bera, A. (1987). A Test for Normality of Observations and Regression Residuals, International Statistical Review, 55: 163-172.

KOTHARI, S. P., Warner, J. B. (2006). Econometrics of Event Studies, Chapter 1 in Handbook of Corporate Finance: Empirical Corporate Finance.

LIU, Y., Zhou, X., Yang, J., Hoepner, A. G. (2017). Corporate Carbon Emissions and Financial Performance: Does Carbon Disclosure Mediate the Relationship in the UK?, SSRN 2941123.

MURGUIA, J. M., Lence, S. H. (2015). Investors' Reaction to Environmental Performance: A Global Perspective of the Newsweek's “Green Rankings", Environmental and Resource Economics, 60(4): 583-605.

MURRAY, A., Sinclair, D., Power, D., Gray, R. (2006). Do Financial Markets Care About Social and Environmental Disclosure?, Accounting, Auditing \& Accountability Journal, 19(2): 228-255.

PELOZA, J. (2009). The Challenge of Measuring Financial Impacts from Investments in Corporate Social Performance, Journal of Management, 35(6): 1518-1541.

R CORE TEAM (2020). R: A language and Environment for Statistical Computing. R Foundation for Statistical Computing, Vienna, Austria. URL https://www.R-project.org/

RUDNYTSKYI, I. (2019). Estudy2: An Implementation of Parametric and Nonparametric Event Study. R package version 0.9.1.

SHAKIL, M.H., Mahmood, N., Tasnia, M., Munim, Z.H. (2019), Do environmental, Social and Governance Performance Affect the Financial Performance of Banks? A Cross-Country Study of Emerging Market Banks, Management of Environmental Quality, 30(6): 1331-1344.

SUSTAINABILITY REPORTING, https://en.wikipedia.org/wiki/Sustainability_reporting (Accessed on: February 6, 2021).

TELLIS, G.J., Johnson, J. (2007). The Value of Quality, Marketing Science, 26(6): 758-773.

WASARA, T. M., Ganda, F. (2019). The Relationship Between Corporate Sustainability Disclosure and Firm Financial Performance in Johannesburg Stock Exchange (Jse) Listed Mining Companies, Sustainability, 11(16): 4496.

WONG, KTK. (2017). A Literature Review on Environmental, Social and Governance Reporting and Its Impact on Financial Performance, Austin Journal of Business Administration and Management, 1(4): 1016.

ZIEGLER, A., Busch, T., Hoffmann, V. H. (2011). Disclosed Corporate Responses to Climate Change and Stock Performances: An International Empirical Analysis, Energy Economics, 33(6): 1283-1294. 